Click www.researchjournal.co.in/online/subdetail.html to purchase.

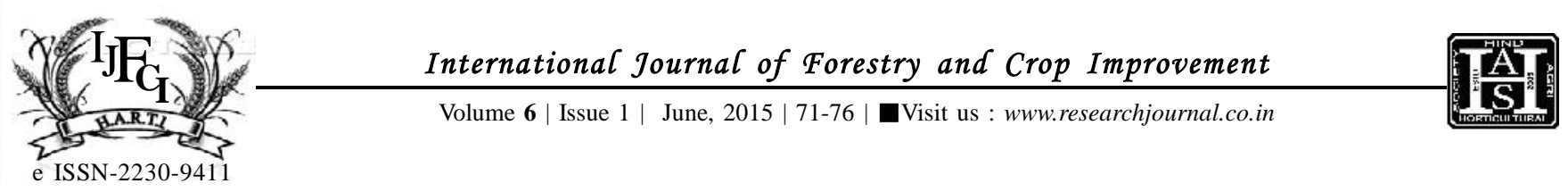

RESEARCH ARTICLE

DOI: $10.15740 / \mathrm{HAS} / \mathrm{IJFCI} / 6.1 / 71-76$

\title{
Fuel wood, fodder and timber consumption status in a forest fringe tribal society of Jharkhand
}

\author{
CHANDRAMOLLY AND M.A. ISLAM
}

\begin{abstract}
The study examines the nature and extent of fuel wood, fodder and timber dependence in nearby forests by the local people living in Rarha village of Ranchi district in Jharkhand, India. A field survey of 72 households from the village was conducted for collecting primary data about the basic household's attributes, dependency on fuel wood, fodder and timber and consumption pattern of these forest resources through a well-structured pre-tested interview schedule, personal observations, focus group discussion and participatory rural appraisal using multi-stage random sampling technique. Simple descriptive methods are used to analyse the data. The investigation revealed that the consumption of fuel wood was maximum (50.94 qt

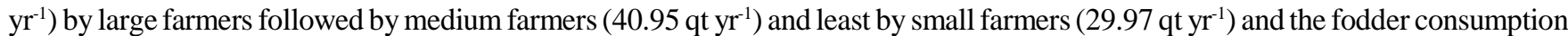

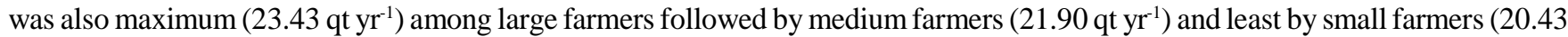

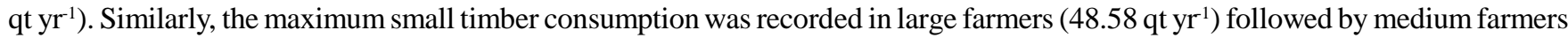
(42.54 $\mathrm{qt} \mathrm{yr}^{-1}$ ) and least by small farmers (39.49 $\left.\mathrm{qt} \mathrm{yr}^{-1}\right)$. As regards structural timber consumption, the amount consumed by large

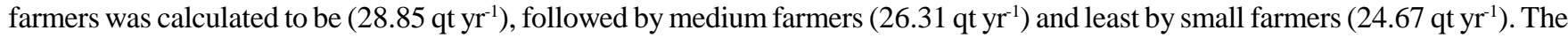
forests are facing enormous pressure for securing the needs by the local people, posing great threat to the biodiversity and environment. Therefore, the forest resources conservation through the intervention of alternative avenues is imperative to keep pace with current development and future challenges in the village.
\end{abstract}

KEY WORDS : Fuel wood, Fodder, Timber, Forest, Tribal society

How TO CITE THIS ARTICLE : Chandramolly and Islam, M.A. (2015). Fuel wood, fodder and timber consumption status in a forest fringe tribal society of Jharkhand. Internat. J. Forestry \& Crop Improv., 6 (1) : 71-76.

ARTICle ChroniCAL : Received : 24.03.2015; Revised : 28.04.2015; Accepted : 30.05.2015

MEMBERS OF RESEARCH FORUM

Address of the Correspondence : M.A. ISLAM, Faculty of Forestry, Sher-e-Kashmir

University of Agricultural Sciences and Technology (K) Wadura, SOPORE (J\& K) INDIA Email: ajaz_jsr@yahoo.co.in, ajaztata@gmail.com

Address of the Coopted Authors : CHANDRAMOLLY, Agricultural Technology Management Agency, Chhatarmandu, RAMGARH (JHARKHAND) INDIA 